\title{
Eksplorasi Hasil Belajar Matematika melalui Penerapan Sistem Pembelajaran Daring (SIPEDAR) di Masa Pandemi COVID-19
}

\author{
Trisniawati $^{* 1}$, Mahmudah Titi Muanifah ${ }^{2}$, Nelly Rhosyida ${ }^{3}$, Rosidah Aliim Hidayat ${ }^{4}$ \\ ${ }^{1,2}$ Program Studi Pendidikan Guru Sekolah Dasar, Universitas Sarjanawiyata Tamansiswa \\ *trisniawati.87@gmail.com
}

\begin{abstract}
ABSTRAK
Penelitian ini bertujuan untuk mendeskripsikan hasil belajar siswa melalui penerapan Sistem Pembelajaran Daring (SIPEDAR) di masa pandemi COVID-19 dan mengetahui fitur- fitur apa saja yang digunakan pada pembelajaran melalui SIPEDAR seperti assignment (tugas), attendance (presensi), bigbluebottonBN, choice, database, external tool, feedback, forum, glossary, kuis, obrolan, kuis, pelajaran, scrom package, survei, workshop, buku, file, folder, IMS content package, label, page, dan URL. Jenis penelitian ini adalah penelitian kualitatif. Subjek pada penelitian ini adalah mahasiswa semester III yang mengambil mata kuliah Matematika SD Kelas Tinggi pada program studi pendidikan guru sekolah dasar di Universitas Sarjanawiyata Tamansiswa. Instrumen yang digunakan berupa soal yang berbentuk pilihan ganda, pernyataan benar salah, dan uraian. Hasil penelitian yaitu rata-rata skor kuis dan rata-rata nilai tugas pada kelas 3A yaitu 83.27 dan 72.90. Rata-rata skor kuis dan rata-rata nilai tugas pada kelas 3F yaitu 83.56 dan 70.67. Hasil belajar siswa pada kedua kelas termasuk dalam kategori baik sehingga pembelajaran menggunakan SIPEDAR terlaksana dengan baik dan dapat dimodifikasi dengan platform e-learning lain.
\end{abstract}

Kata kunci: SIPEDAR, hasil belajar, matematika.

\begin{abstract}
This study aims to describe student learning outcomes through the application of the online learning system (SIPEDAR) during the COVID-19 pandemic and to find out what features are used in learning through SIPEDAR such as assignment (assignment), attendance (presence), bigbluebottonBN, choice, databases, external tools, feedback, forums, glossaries, quizzes, chats, quizzes, lessons, scrom packages, surveys, workshops, books, files, folders, IMS content packages, labels, pages, and URLs. This type of research is qualitative research. The subjects in this study were third semester students who took Mathematics at Elementary School Class High in the elementary school teacher education study program at Universitas Sarjanawiyata Tamansiswa. The instruments used were in the form of multiple choice questions, true false statements, and descriptions. The results of the study were the average quiz score and the average assignment score in class $3 \mathrm{~A}$, namely 83.27 and 72.90 . The average quiz score and the average assignment score in the $3 \mathrm{~F}$ class were 83.56 and 70.67 . Student learning outcomes in both classes are included in the good category so that learning using SIPEDAR is carried out well and can be modified with other e-learning platforms.
\end{abstract}

Keywords: SIPEDAR, learning outcomes, mathematics.

Received: 2021-03-24

/ Accepted: 2021-04-17

/ Published: 2021-05-01

\section{Pendahuluan}

Kondisi saat ini yang berbeda dari sebelumnya karena pandemi COVID-19 merubah segala aktivitas tidak terkecuali pada bidang pendidikan. Siswa yang awalnya biasanya datang ke sekolah dengan menggunakan seragam tiap pagi atau siang sudah tidak dilakukan lagi. Pembelajaran saat ini melibatkan teknologi yang berbasis internet. Tatap muka sudah tidak dilakukan lagi sebagai upaya menekan penyebaran virus COVID-19 (Handayani \& Irawan, 2020). Berdasarkan surat edaran nomor 4 tahun 2020 mengenai Pelaksanaan Kebijakan Pendidikan dalam Masa Darurat Penyebaran COVID-19 oleh Menteri Pendidikan dan Kebudayaan RI tanggal 24 Maret 2020, Nadiem Anwar Makarim terdapat beberapa kebijakan mengenai kegiatan pembelaran selama masa pandemi ini. Terdapat 6 (enam) kebijakan yang dipaparkan dengan jelas, diantaranya merubah cara belajar mengajar pendidik 
TRISNIAWATI, MAHMUDAH TITI MUANIFAH, NELLY RHOSYIDA, ROSIDAH ALIIM HIDAYAT

Eksplorasi Hasil Belajar Matematika melalui Penerapan Sistem Pembelajaran Daring (SIPEDAR) di Masa Pandemi COVID-19

dan peserta didik yaitu kebijakan belajar dari rumah. Kebijakan belajar dari rumah yang diambil oleh pemerintah tersebut, menuntut guru dan dosen harus melakukan penyesuaian proses pembelajaran dengan cepat (Winarti, 2021). Pelaksanaan pembelajaran daring memungkinkan terjadi secara jarak jauh yang memungkinkan pendidik dan peserta didik berada pada tempat yang berbeda sehingga pembelajaran tidak tatap muka dalam satu tempat (Trisniawati et al., 2020). Pendidik harus menyesuaikan proses pembelajaran yang biasanya dilakukan dengan tatap muka diganti menjadi pembelajaran secara daring. Kegiatan pembelajaran daring ini dilakukan untuk mengganti kegiatan pembelajaran secara langsung (Mukhalafatun \& Hanan, 2020). Dengan media pembelajaran online ini peserta didik menggunakan fasilitas internet supaya bisa berkomunikasi dan menyalurkan materi secara online dengan jarak yang jauh.

Dalam hal ini penggunaan internet tidak hanya untuk bersosial media ataupun penggunaan game online akan tetapi internet juga bisa dijadikan media pembelajaran sehingga dapat menunjang pembelajaran siswa apalagi diera pandemi COVID-19 ini (Ainur Risalah et al., 2020). Dampak positif dari hal tersebut adalah pendidik dapat lebih banyak mengeksplorasi dalam melakukan pembelajaran daring melalui berbagai macam fitur sistem pembelajaran. Menurut (Widiyasari, 2017) e-learning dapat memberikan banyak manfaat yaitu dapat menggunakan bahan ajar yang varitif serta waktunya lebih flexible. Hal ini memungkinkan peserta didik secara aktif dan kreatif dalam proses pembelajaran secara daring. Dalam hal segi positif pembelajaran daring sangat membantu terutama pada masa pandemi COVID-19 seperti sekarang ini yaitu dalam hal menjaga keamanan dan keselamatan baik pendidik maupun peserta didik karena berada di rumah masing-masing dan mencegah terjadinya penularan virus COVID-19 dengan tidak berkerumun di kelas secara tatap muka. Selain itu menurut (Dewantara, 2018) segi positif lainnya yaitu peserta didik akan mengembangkan idenya untuk memecahkan permasalahan pada proses pembelajaran dan akan berdiskusi dengan ide-ide dari peserta didik yang lain. Pembelajaran secara daring juga mengoptimalkan hasil belajar dalam hal ini mahasiswa dengan penguasaan konsep melalui diskusi, kuis, tugas dan webmeeting. Hasil belajar merupakan suatu ukuran berhasil tidaknya seorang siswa dalam proses belajar mengajar (Ekawati, 2013). Hasil belajar adalah kemampuan yang dimiliki siswa setelah merekamenerima pengalaman belajar dalam proses pembelajaran (Nurdyansyah \& Toyiba, 2016). Hasil belajar matematika merupakan salah satu indikator keefektifan pembelajaran matematika. Hasil belajar matematika yang tinggi menunjukkan bahwa proses belajar matematika tersebut efektif.

Terkait dengan aspek cara penyampaian dosen dalam penguasaan materi dan penguasaan penggunaan platform online, mahasiswa menganggap dosen cukup baik dalam penggunaan aplikasi. Pelaksanaan pembelajaran daring di Universitas Sarjanawiyata Tamansiswa sebelumnya secara bebas menggunakan aplikasi yang tersedia, seperti edmodo, google classroom, dll. Platform Online yang sering digunakan selama pembelajaran antara lain Whats App Group (WAG), Google Classroom $(G C)$, Edmodo, dan Zoom (Rachmawati et al., 2020). Hal tersebut dikarenakan belum ada sistem pembelajaran daring ketika awal pandemi. Setelah ada sistem pembelajaran daring (SIPEDAR) maka pembelajaran daring yang digunakan melalui SIPEDAR. Dalam hal ini penggunaan sistem pembelajaran daring (SIPEDAR) yang difasilitasi kampus telah terintegrasi dengan portal mahasiswa dapat dimanfaatkan sebagai platform utama pembelajaran di kampus. Sistem informasi pembelajaran daring (SIPEDAR) merupakan platform e-learning yang bersesuaian dengan moodle yang sudah terintegrasi dengan portal mahasiswa. Civitas akademik kampus dapat mengakses SIPEDAR melalui website sipedar.ustjogja.ac.id dan login dengan username dan password yang sama dengan portal akademik. Fitur yang ada di SIPEDAR diantaranya yaitu assignment (tugas), attendance

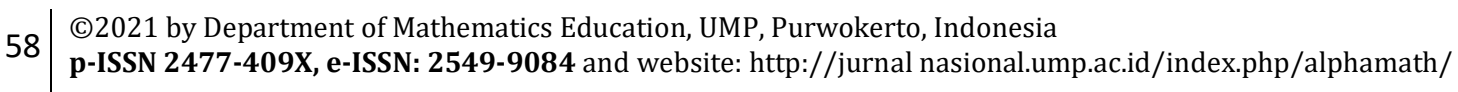


(presensi), bigbluebottonBN, choice, database, external tool, feedback, forum, glossary, kuis, obrolan, kuis, pelajaran, scrom package, survei, workshop, buku, file, folder, IMS content package, label, page, dan URL. Berdasarkan pemaparan diatas maka tujuan penelitian mendeskripsikan hasil belajar siswa melalui penerapan sistem pembelajaran daring (SIPEDAR) di masa pandemi COVID-19 dan mengetahui fitur- fitur apa saja yang digunakan pada pembelajaran melalui SIPEDAR.

\section{Metode Penelitian}

Jenis penelitian adalah penelitian kualitatif dan menggunakan sumber data primer, serta pengumpulan data dilakukan secara mendalam. Teknik pengumpulan data pada penelitian ini menggunakan observasi berperan serta (participant observation), wawancara, dokumentasi, dan tes berupa soal. Subjek penelitian adalah mahasiswa semester III yang menempuh mata kuliah Matematika SD Kelas Tinggi pada program studi Pendidikan Guru Sekolah Dasar di Universitas Sarjanawiyata Tamansiswa. Instrumen pada penelitian ini yaitu soal-soal pemecahan masalah di SIPEDAR dengan memanfaatkan fitur kuis, tugas dan diskusi pemecahan masalah. Metode penelitian yang digunakan yaitu dengan tiga tahap meliputi reduksi data, penyajian data, dan penarikan kesimpulan/verifikasi. Data tersebut kemudian diperiksa keabsahannya dengan memenuhi 4 standar yaitu (1) derajat kepercayaan (credibility), (2) keteralihan (transferability), (3) kebergantungan (dependability), dan (4) kepastian (confirmability) (Moleong, 2005).

\section{Hasil dan Pembahasan}

Pelaksanaan pembelajaran online melalui SIPEDAR dimulai semester gasal 2020/2021 yaitu dengan memberikan rencana pembelajaran semester (RPS), pemberian kontrak perkuliahan, bahan pembelajaran, video pembelajaran, kuis, tugas, forum diskusi pemecahan masalah, dan webmeeting dengan pelaksanaan full daring dari rumah masing-masing sehingga mahasiswa selain mengakses SIPEDAR juga didalamnya terdapat webmeeting menggunakan bigbluebotton $B N$ sehingga mahasiswa tetap bisa presentasi seperti biasa seperti luring, hanya ini dengan daring. Pelaksanaan pembelajaran melalui SIPEDAR dibagi menurut kelas sesuai dengan jadwal yang ditentukan oleh prodi PGSD Universtitas Sarjanawiayata Tamansiswa dan terintegrasi dengan portal akademik mahasiswa, masing-masing mahasiswa dapat login sesuai dengan username dan password portal mahasiswa. Diskusi diberikan pada saat pembelajaran kemudian setelah webmeeting, mahasiswa mengerjakan kuis untuk mengetahui pemahaman materi mahasiswa berupa soal pemecahan masalah dan UTS serta UAS berupa soal pemecahan masalah menggunakan forum diskusi. Mahasiswa yang menempuh mata kuliah Matematika SD kelas tinggi pada semester III yaitu kelas 3A dan 3F. Kelas 3A terdapat 43 mahasiswa dan kelas $3 \mathrm{~F}$ terdapat 37 mahasiswa. Berikut ini tabel rekapan hasil kuis dan tugas mahasiswa kelas $3 \mathrm{~A}$ dan $3 \mathrm{~F}$.

Tabel 1. Rekapan Hasil Kuis dan Tugas Mahasiswa

\begin{tabular}{cccc}
\hline $\begin{array}{c}\text { Semester/Kel } \\
\text { as }\end{array}$ & $\begin{array}{c}\text { Rata-rata nilai } \\
\text { kuis }\end{array}$ & $\begin{array}{c}\text { Rata-rata nilai } \\
\text { tugas }\end{array}$ & Keterangan \\
\hline 3/A & 83.27 & 72.90 & Kategori Baik \\
3/F & 83.56 & 70.67 & Kategori Baik \\
\hline
\end{tabular}

Berdasarkan Tabel 1 di atas terlihat kedua kelas 3A maupun 3F berada dalam kategori baik berdasarkan nilai rata-rata kuis dan tugas. Kelas $3 \mathrm{~A}$ memperoleh rata-rata lebih tinggi dari kelas $3 \mathrm{~F}$ baik dalam hal nilai kuis ataupun tugas. 
TRISNIAWATI, MAHMUDAH TITI MUANIFAH, NELLY RHOSYIDA, ROSIDAH ALIIM HIDAYAT

Eksplorasi Hasil Belajar Matematika melalui Penerapan Sistem Pembelajaran Daring (SIPEDAR) di Masa Pandemi COVID-19

Pelaksanaan pembelajaran daring pada mata kuliah Matematika SD Kelas Tinggi pada SIPEDAR diawali sesuai dengan kelas yang terjadwal di prodi. Pada pertemuan pertama, dosen memberikan Rencana Pembelajaran Semester (RPS), kontrak perkuliahan, serta membagi presentasi mahasiswa. Kemudian dosen memberikan bahan dan video pembelajaran pada masing-masing pertemuan. Mahasiswa mengkonsultasikan materi yang akan dipresentasikan ke dosen terlebih dahulu, kemudian menambahkan atau merevisi sesuai dengan saran dosen. Selanjutnya materi tersebut di share di SIPEDAR melalui forum diskusi. Berdasarkan hasil observasi di SIPEDAR pada forum diskusi ini, mahassiswa dan dosen akan mempelajari materi yang telah di upload dan mendiskusikan materi dan video pembelajaran serta mengerjakan soal dengan add topic discussion dengan cara memberikan komentar atau mengupload foto hasil jawaban dari soal pemecahan masalah yang diberikan oleh pemakalah. Setelah itu kelompok mempresentasikan dengan melaksanakan webmeeting menggunakan fitur bigbluebotton $B N$. Selanjutnya mahasiswa lain akan menanggapi ketika webmeeting, apabila ada pertanyaan maka pemakalah dan dosen mendiskusikan dan memberikan feedback atau masukan. Pada setiap akhir webmeeting, dosen memberikan kesimpulan dan refleksi setiap pembelajaran. Webmeeting ini tidak berjalan full selama jam perkuliahan. Berikut ini beberapa contoh diskusi yang ada dalam SIPEDAR:

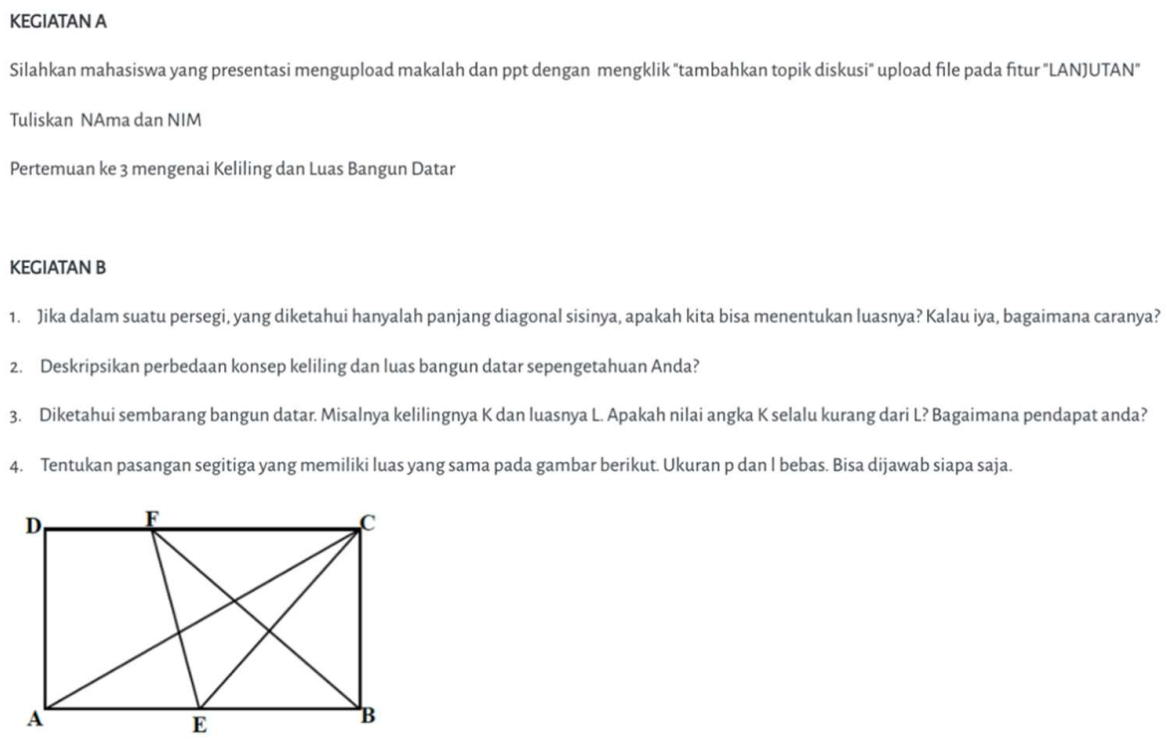

Gambar 1. Contoh diskusi di SIPEDAR

Pada forum diskusi pemecahan masalah, mahasiswa secara aktif dan disiplin sesuai dengan jam perkuliahan mendiskusikan soal pemecahan masalah yang ada di SIPEDAR. Hal tersebut dapat dilihat pada Gambar 1 terlihat mahasiswa banyak memberikan komentar dengan cara add new topic discussion yaitu dengan secara aktif mendiskusikan dan mengerjakan soal yang diberikan oleh kelompok. Pada kegiatan diskusi di SIPEDAR ini berjalan lancar dan mahasiswa aktif memberikan pendapat, mengerjakan soal, dan mempelajari materi yang telah diupload oleh pemakalah. Selanjutnya mahasiswa mengerjakan kuis yang telah dibuat oleh dosen pada hari perkuliahan pada masing- masing pertemuan dan diberikan waktu 1x24 jam untuk mengerjakan kuis tersebut. Kuis yang dibuat oleh dosen berupa soal pemecahan masalah dengan bentuk pilihan ganda, benar salah, dan soal uraian. Kesempatan mengerjakan kuis hanya satu kali, namun ada beberapa mahasiswa yang ditengah mengerjakan kuis mengalami kesulitan sinyal, sehingga dosen memberikan

$60 \mid \begin{aligned} & \text { C2021 by Department of Mathematics Education, UMP, Purwokerto, Indonesia } \\ & \text { p-ISSN 2477-409X, e-ISSN: 2549-9084 and website: http://jurnal nasional.ump.ac.id/index.php/alphamath/ }\end{aligned}$ 
kesempatan sekali lagi untuk mahasiswa mengerjakan kuis. Berikut ini contoh kuis di SIPEDAR yang diberikan pada pembelajaran:

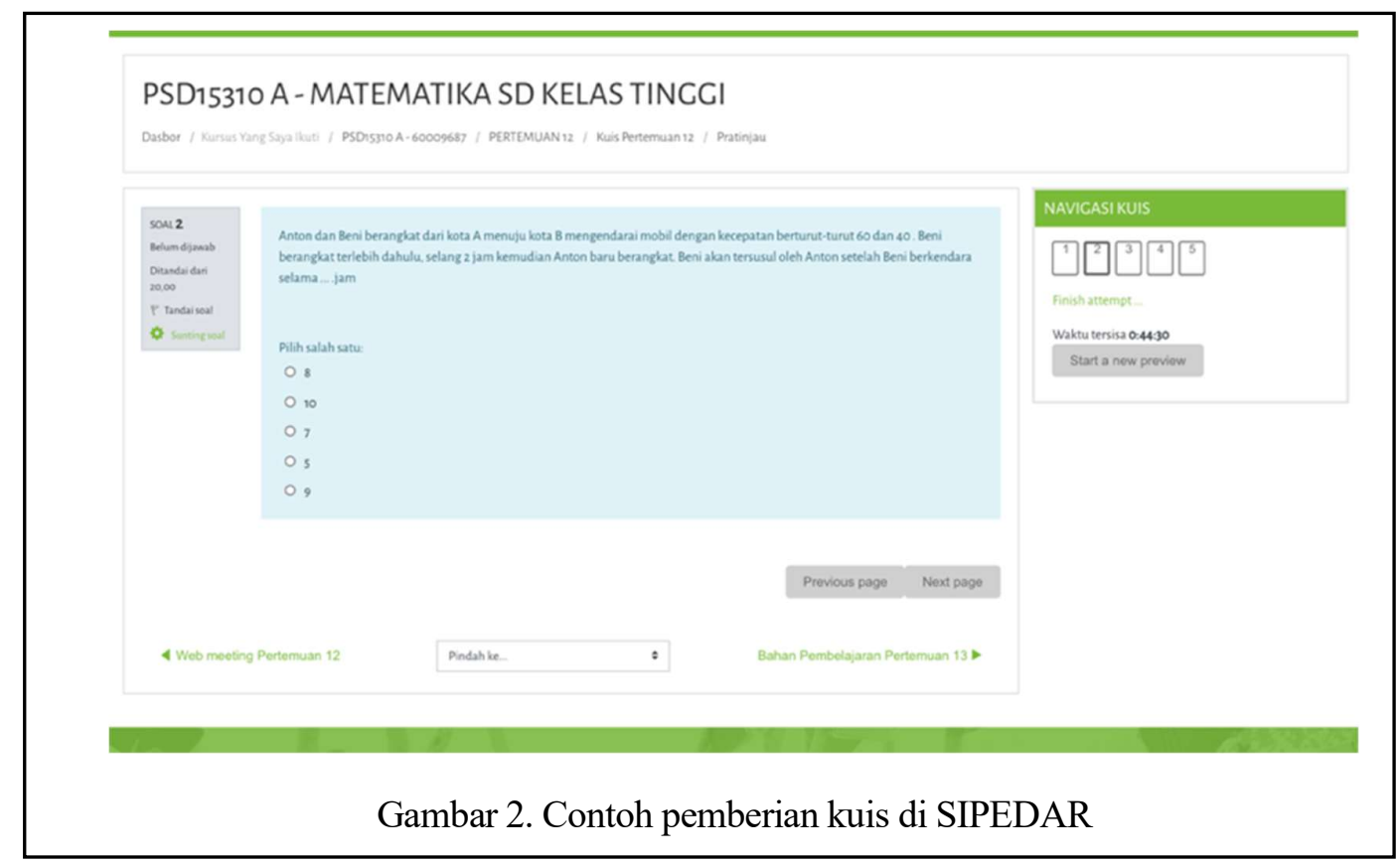

Pada saat mahasiswa mengerjakan kuis pada SIPEDAR dapat melatih kemandirian dan berpikir tingkat tinggi mahasiswa. Pada Gambar 2 bahwa mahasiswa mengerjakan kuis tepat waktu, kemudian apabila mahasiswa mengalami kesulitan maka akan ditanyakan di pertemuan selanjutnya dan mahasiswa dapat bertanya melalui webmeeting atau pada kolom komentar di forum diskusi. Berdasarkan Tabel 1 pada mata kuliah Matematika SD Kelas Tinggi mahasiswa mengalami kesulitan saat mengerjakan kuis pada materi transformasi geometri dan hubungan jarak. Materi yang dipelajari pada mata kuliah matematika SD kelas tinggi yaitu hubungan jarak, waktu dan kecepatan; bangun datar; bangun ruang; simetri; satuan pengukuran; perbandingan; dan transformasi geometri. Pembelajaran menggunakan webmeeting dan juga SIPEDAR yaitu mahasiswa presentasi sesuai dengan pembagian kelompoknya masing-masing. Selanjutnya dosen memberikan penguatan materi ketika webmeeting dan memberikan video pembelajaran untuk memahamkan materi. Berikut ini contoh webmeeting menggunakan bigbluebottonBN melalui SIPEDAR (Gambar 3).

Setelah memberikan kuis, fitur yang digunakan dosen yaitu fitur polling, misalnya terhadap webmeeting yang digunakan ingin menggunakan bigbluebotton $B N$ atau meet atau zoom, kemudian pada pelaksanaan ujian tengah semester pada SIPEDAR. Pada pelaksanaan UTS, dosen menggunakan fitur assignmen tugas di SIPEDAR, selanjutnya dosen mengupload soal UTS di SIPEDAR dan mengatur waktu ujian. Mahasiswa mengerjakan soal UTS di kertas dan diberi nama secara mandiri dirumah masing-masing. Jawaban soal kemudian di foto dan disatukan file word atau pdf dengan ukuran kurang dari $5 \mathrm{mb}$ serta diunggah di SIPEDAR. Ada beberapa kendala yang dihadapi saat pelaksanaan UTS diantaranya kendala sinyal yang menyebabkan keterlambatan pengumpulan dan tidak bisa mengumpulkan karena waktu sudah terkunci di sistem SIPEDAR. Dalam hal ini dosen mengubah setting waktu agar mahasiswa tetap mengumpulkan walaupun terlambat dan memberikan kesempatan upload ulang. Cara lain yaitu melalui whatsapp secara pribadi ke dosen kemudian mahasiswa mengirimkan jawabannya melalui whatsapp. Kendala lain 
TRISNIAWATI, MAHMUDAH TITI MUANIFAH, NELLY RHOSYIDA, ROSIDAH ALIIM HIDAYAT

Eksplorasi Hasil Belajar Matematika melalui Penerapan Sistem Pembelajaran Daring (SIPEDAR) di Masa Pandemi COVID-19

yaitu foto yang tidak fokus atau blur pada file jawaban soal yang diupload oleh mahasiswa. Dalam hal ini dosen memberikan kesempatan agar mahasiswa mengupload kembali dengan foto jawaban soal yang fokus dan tidak blur. Kemudian dalam webmeeting menggunakan bigbluebotton $B N$ terdapat beberapa kendala seperti audio mahasiswa tidak support untuk berbicara, hanya bisa mendengar, juga ada beberapa yang terkendala ketika share screen untuk presentasi. Dalam hal ini dosen memberikan alternatif untuk melaksanakan webmeeting melalui google meet, kemudian link hasil rekaman webmeeting diberikan melalui SIPEDAR. Berdasarkan Tabel 1, diatas terlihat kedua kelas 3A maupun 3F berada dalam kategori baik berdasarkan nilai rata-rata kuis dan tugas. Kendala yang dihadapi pada pembelajaran daring diselesaikan dengan baik karena terdapat kerjasama dan komunikasi yang baik antara mahasiswa maupun dosen. Hal ini sesuai dengan pembelajaran dengan aplikasi moodle lebih memfasilitasi siswa untuk berinteraksi baik secara individual maupun dengan teman-teman lainnya (Abdul \& Ulfah, 2012).

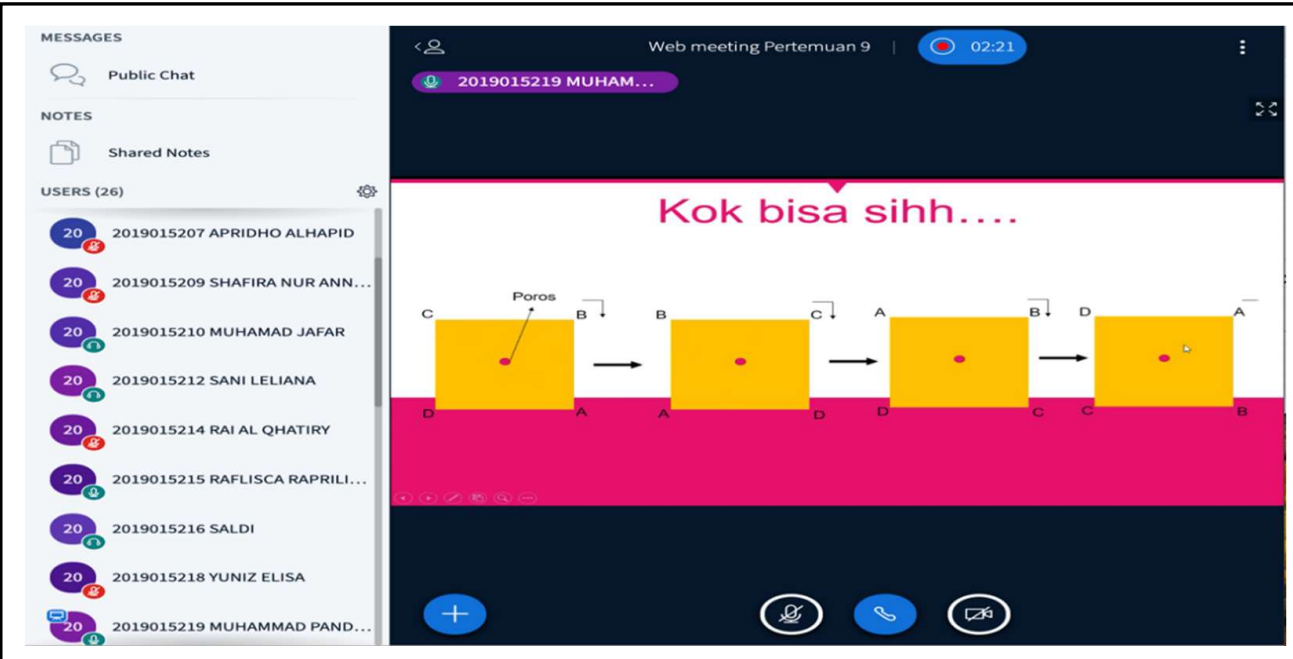

Gambar 3. Contoh penggunaan bigbluebottonBN di SIPEDAR

\section{Simpulan}

Pelaksanaan pembelajaran daring melalui SIPEDAR dilaksanakan rencana pembelajaran semester (RPS), pemberian kontrak perkuliahan, bahan pembelajaran, video pembelajaran, kuis, tugas, forum diskusi pemecahan masalah, dan webmeeting. Fitur yang ada di SIPEDAR diantaranya yaitu assignment (tugas), attendance (presensi), bigbluebottonBN, choice, database, external tool, feedback, forum, glossary, kuis, obrolan, kuis, pelajaran, scrom package, survei, workshop, buku, file, folder, IMS content package, label, page, dan URL. Mahasiswa disiplin mengikuti jadwal perkuliahan serta aktif mengikuti diskusi, menyelesaikan tugas yang diberikan, serta diakhir pembelajaran mengerjakan kuis yang ada di SIPEDAR untuk mengetahui pemahaman terhadap materi setiap pertemuan. Webmeeting presentasi kelompok juga berjalan lancar, walaupun ada mahasiswa yang susah sinyal. Mahasiswa disiplin, aktif, dan mempunyai komitmen mengikuti perkuliahan dan mengerjakan kuis. Mahasiswa juga aktif dan disiplin pada pelaksanaan ujian tengah semester di SIPEDAR mahasiwa yaitu ada beberapa ng bertanya jika ada petunjuk soal yang belum jelas. Kedua kelas 3A maupun $3 \mathrm{~F}$ berada dalam kategori baik berdasarkan nilai rata-rata kuis dan tugas. Diharapkan dengan pembelajaran melalui SIPEDAR yang sudah terintegrasi dengan sistem portal mahasiswa, maka dosen dapat lebih mempelajari lebih lanjut mengenai fitur kuis yang ada pada SIPEDAR, misalkan tidak hanya menggunakan pilihan ganda, uraiaan atau pernyataan benar

62 | $\begin{aligned} & \text { C2021 by Department of Mathematics Education, UMP, Purwokerto, Indonesia } \\ & \text { p-ISSN 2477-409X, e-ISSN: 2549-9084 and website: http://jurnal nasional.ump.ac.id/index.php/alphamath/ }\end{aligned}$ 
salah tetapi menggunakan soal dengan tipe yang berbeda-beda. Pembelajaran melalui SIPEDAR yang selanjutnya juga tetap dilaksanakan dengan berbagai modifikasi platform pembelajaran online lainnya.

\section{Daftar Pustaka}

Abdul, M., \& Ulfah, R. M. (2012). Dengan Pembelajaran Menggunakan Aplikasi. Pythagoras, 7(1). http://eprints.umsida.ac.id/id/eprint/1610

Ainur Risalah, W Ibad, L Maghfiroh, M I Azza, S A Cahyani, \& Z A Ulfayati. (2020). Dampak Pandemi COVID-19 Terhadap Kegiatan Belajar Mengajar Di MI/SD (Studi KBM Berbasis Daring Bagi Guru dan Siswa). JIEES: Journal of Islamic Education at Elementary School, 1(1), 10-16. https://doi.org/10.47400/jiees.v1i1.5

Dewantara, D. (2018). Perbedaan Kemampuan Analisis Mahasiswa Antara Pembelajaran Berbantuan Schoology dan Edmodo Pada Mata Kuliah Fisika Biologi. Prisma Sains: Jurnal Pengkajian Ilmu Dan Pembelajaran Matematika Dan IPA IKIP Mataram, 6(1), 1. https://doi.org/10.33394/j-ps.v6i1.826

Ekawati, S. (2013). Pengaruh kedisiplinan dan aktivitas belajar terhadap hasil belajar matematika siswa. Pedagogik, 1(2), 119-130. https://journal.uncp.ac.id/index.php/Pedagogy/article/view/361/321

Handayani, S. D., \& Irawan, A. (2020). Pembelajaran matematika di masa pandemic COVID19 berdasarkan pendekatan matematika realistik. Jurnal Math Educator Nusantara: Wahana Publikasi Karya Tulis Ilmiah Di Bidang Pendidikan Matematika, 6(2), 179-189. https://doi.org/10.29407/jmen.v6i2.14813

Moleong, M. . (2005). Metodologi Penelitian Kualitatif. PT Remaja Rosdakarya.

Mukhalafatun, S., \& Hanan, H. (2020). Studi Eksploratif Dampak Pandemi COVID-19 terhadap Proses Pembelajaran E-Learning Di Perguruan Tinggi. UrbanGreen Conference Proceeding Library, 1(1), 78-83. https://ummaspul.ejournal.id/Edupsycouns/article/view/397

Nurdyansyah, \& Toyiba, F. (2016). Pengaruh Strategi Pembelajaran Aktif terhadap Hasil Belajar Pada Madrasah Ibtidaiyah. Strategi Pembelajaran Aktif, Hasil Belajar, 1(2), 929 930. http://eprints.umsida.ac.id/id/eprint/1610

Rachmawati, Y., Ma'arif, M., Fadhillah, N., Inayah, N., Ummah, K., Siregar, M. N. F., Amalyaningsih, R., C., F. A. A., \& F., A. A. (2020). Studi Eksplorasi Pembelajaran Pendidikan IPA Saat Masa Pandemi COVID-19 di UIN Sunan Ampel Surabaya. Indonesian Journal of Science Learning, Volume 1,(1), 32-36. http://jurnalftk.uinsby.ac.id/index.php/IJSL/article/view/633

Trisniawati, T., Rhosyida, N., \& Muanifah, M. T. (2020). Eksplorasi Hasil Belajar Mahasiswa melalui Penggunaan Kuis dan Tugas pada E-learning Edmodo di Era Pandemi COVID19. 6(2), 39-47. https://doi.org/10.30738/jst.v6i2.8049

Widiyasari, R. (2017). Meningkatkan Aktivitas dan Hasil Belajar Mahasiswa Menggunakan Mind Map Berbantuan E - Learning Increasing Students 'Learning Activity and. 27-43.

Winarti, P. (2021). Analisis Kesulitan Belajar Mahasiswa dalam Perkuliahan Konsep Dasar IPA Fisika Secara Daring di Masa Pandemi COVID-19. Jurnal Komunikasi Pendidikan, 5(1), 93. https://doi.org/10.32585/jkp.v5i1.1076 